Militaria w kreacji świata przedstawionego powieści Stefana Żeromskiego. Pisarz wobec nowych środków walki

Ryszard Handke 


\section{Ryszard Handke}

\section{Militaria w kreacji świata przedstawionego powieści Stefana Żeromskiego. Pisarz wobec nowych środków walki}

$\mathrm{W}$ ielka wojna ogromnie wzbogaciła arsenał środków zabijania. W technice wojskowej dokonał się przełom tak wielki, że druga wojna światowa mogła głównie doskonalić zdobycze poprzedniczki, ograniczając swój samodzielny wkład do pocisków kumulacyjnych, dział bezodrzutowych i bomby atomowej.

W powieściach Żeromskiego, których akcje rozgrywają się w tym czasie i zostały umiejscowione na ziemiach polskich i epizodycznie na Zakaukaziu, nowości techniki wojennej prezentują się skromnie. W znacznej mierze wynika to z perspektywy oglądania przez autora rzeczywistości będącej materiałem i fundamentem jego literackich przetworzeń. Fronty przebiegające przez nasz kraj nie były ani drugorzędne, ani mniej straszne w skutkach. Jednak przestrzenie wschodniego teatru wojny zmniejszyły skupienie środków i wpływały na ich wybór. Gazy, czołgi, masowo użyte samoloty bojowe wystąpiły po raz pierwszy, a czasami jedynie, na zachodzie.

Szczególnym zainteresowaniem pisarz darzył Legiony jako pierwsze polskie wojsko, ale trudne dzieje tej formacji wskazują na jej traktowanie po macoszemu przez militarnie zacofaną Austrię. Wybrakowany sprzęt daleki był od najświeższych osiagnnięć w dziedzinie techniki wojskowej ${ }^{1}$.

Wojna i wojsko przestało również, jak się zdaje, być dla autora zajmujące samo w sobie — nie była to już fascynująca dziedzina dawnej broni i barwy. Potworność przeszłych wojen przerosły, a ich mimo wszystko malowniczość przesłoniły nieznane w tej postaci i natężeniu mechanizmy

\footnotetext{
1 W dziedzinic artylerii, a wį̨c podstawowcj, fatalny stan wyposażcnia Legionów przcdstawia miçdzy innymi R. Łoś, Artyleria polska 1914-1939, Warszawa 1991, s. 14: „W wyniku usilnych starań udało sic̨ uzyskać 20 starych dział górskich wz. 1875 kalibru $70 \mathrm{~mm}$. Działa te nie miały oporopowrotników (...) strzclały jeszcze prochem dymnym $(\ldots)$.
} 
ludobójstwa, z walką bezpośrednio niezwiązanego. Ważne jednak przede wszystkim stało się to, co miało nadejść i czego rodzenie się pisarz obserwował z największą uwagą.

Pisarz mierzył się z zadaniem zupełnie nowym. W historycznej batalistyce na wojny chodziło się, teraz ona sama przyszła, miażdżąc swym straszliwym ciężarem ludzkie egzystencje. Nigdy, przynajmniej u Żeromskiego, nie oglądaliśmy jej tylko z powabnej strony, tu jej potworność uzyskała zdecydowanie nowy wymiar. Po raz pierwszy nazwana „światową”, była w istocie totalną (choć jeszcze tego określenia nie używano) wojną cywilów. Realiów militarnych na przykład w Charitas i Przedıviośniu - powieściach o charakterze współczesnym - jest więc generalnie niewiele, przynajmniej jak na epokę, w której pisarz żył.

Słownictwo militarne $\mathrm{w}$ znaczeniach przenośnych, użyte w wyrażeniach silnie nacechowanych stylistycznie, niekiedy $z$ ironicznym dystansem, występuje liczniej w momentach stykania się bohaterów z rzeczywistością powojenną. Patos i potworność, heroizm i nędza wojennej egzystencji muszą być także w płaszczyźnie językowej zneutralizowane ironiczno-żartobliwym dystansem albo wyparte z psychiki przez wyartykułowanie. Stąd tak rzadkie, spokojne, rzeczowe i systematyczne kreowanie słowem militarnych realiów świata utworu.

Ogólnie sprawia to wrażenie, że tak wyraźna w odniesieniu do wcześniejszych okresów pasja przedstawiania świata, również dla samego pisarza fascynującego egzotyką, ustępuje miejsca dążeniu przede wszystkim do wyrażania ważkich przesłań za pośrednictwem świata utworu, w którym troska o prawdę szczegółu przedstawienia wynika przede wszystkim lub wyłącznie z weryzmu naśladownictwa rzeczywistości, bez którego traciłoby na wiarygodności to, co miało być przekazane odbiorcy.

Elementem odróżniającym wojnę, którą Żeromski przedstawia, od batalistyki utworów odnoszących się do epok wcześniejszych są „masy wojska” nieporównywalnie większe, tak że się ich już nie ewidencjonuje i rezygnuje z hiperbolizujących określeń. Nowym pojęciem jest front, „gdy armie stoją naprzeciwko siebie" (Charitas, 216) nie w jakimś określonym miejscu, które stoczona w nim bitwa przeniesie do historii, lecz na przestrzeni setek kilometrów, a gdy zajdzie potrzeba, to i tysięcy. Walczyć nie wyrusza się już w pole, by stanąć w szeregu, lecz na linię właśnie tego frontu. Poza starciami dającymi się wyodrębnić czasowo i przestrzennie oraz konkretnie nazwać trwa „wieczna bitwa, stałe "załamywanie się ataków nieprzyjaciela w ogniu dział przed naszymi wysuniętymi liniami»" (tamże, 262). To następne novum - przywoływanie i kompromitowanie języka masowej komunikacji dotyczącej spraw wojny. Własny język funkcjonuje w przestrzeni już zagospodarowanej, wchodzi w interakcje z cudzymi wypowiedziami, tak ważne dla wymowy całości. Nie bez znaczenia jest, że ten inny język to odindywidualizowany bełkot prymitywnej propagandy.

Teren „zawziętej, iście piekielnej walki między dwiema armiami” (tamże, 279) nie nadaje się już do takich plastycznych przedstawień jak dawniej. „Z ogólnego przebiegu operacji wojennych”

\footnotetext{
${ }^{2}$ Cytaty za wyd.: S. Zeromski, Pisına, red. S. Pigoń, t. 5: Wiatr od morza i inne utwory, Warszawa 1949; t. 16: Walka z szatanem, 1: Nauracanie Judasza. Powieść, Warszawa 1948; t. 18: Walka z szatanem, 3: Charitas. Powieśc, Warszawa 1948; t. 19: Przedwiósnie. Powieś, Warszawa 1949.
} 
wynika „przesunięcie linii wojsk” (tamże, 317), a więc ofensywa i odwrót, jeśli ten wykonuje się np. „staczając (...) zażarte walki z następującymi Moskalami”, dopiero to może stać się okazją, by „w starciu” ktoś „zakomenderował atak na bagnety” (tamże, 299, 156).

„Zajścia wojenne" również w Przedwiośniu potraktowano na ogół syntetycznie i relacją zastępując prezentację. Silniej także zaznaczono próg ludzkiej wytrzymałości, poza którym przeżycia powodują stępienie wrażliwości. Stawało się to niekiedy udziałem bohaterów na przykład Popiotów, dawali temu wyraz lub czynił to za nich narrator, ale nie rezygnowano przy tym z prezentacji obliczonej na wywołanie wstrząsu w odbiorcy.

Walka i walczący w Charitas i Przedwiośniu nie są już tak samoistnie atrakcyjni. Spektakularny paroksyzm starcia wręcz stał się ewenementem, utonął w nędzy i nudzie życia w okopach. Śmierć w krwawej grozie objawiła się znamiennie w scenie egzekucji:

...rozległ się huk zbiorowego strzału dziewięciu karabinów. Czaszka mocnego wieśniaka została powyżej oczu literalnie ścięta, jak gdyby wyciągniętą z pochwy, błyszczącą w dali szablą komenderującego. Sklepienie tej czaszki odskoczyło z głowy jak zdmuchnięta krwawa czapka. Trup, kipiący od bujnej krwi, zachwiał się, posunął po ścianie i runął u drzwi obory (Charitas, 164-165).

Wiele tu artystycznej celowości detali, nawet za cenę dokumentalnego prawdopodobieństwa. Nie chodzi o skutek salwy, a tylko wybór celu trudniejszego do trafienia niż korpus. Dało to jednak możliwość aluzyjnego przeniesienia funkcji narzędzia śmierci na szablę oficera; i on jednak nie jest sprawca, lecz bezduszna i bezosobowa logika wojny. Choć jak wynika z drugiej egzekucji, bezkrwawej a ohydnej przede wszystkim moralnie - to jednak czlowiek uruchamia nieludzkie mechanizmy — nie w bojowym rozjuszeniu, nawet nie podnosząc szabli, by samym jej skinieniem spowodować morderczą salwę. Ten sam zresztą człowiek - tu awangardowy malarz, sprawny frontowy dowódca i wreszcie wojskowy dygnitarz zadekowany wygodnie na tyłach, gotów zdyskontować trud i ryzyko wojenne jako start do cywilnej kariery - załatwił to donosem i przez poczciwie przedstawionych funkcjonariuszy śmierci.

Z malowniczych pól bitew mimo wszystko wojna zeszła do rowów strzeleckich, zwanych także po prostu rowami; często rozgrywa się „w okopach legionów”(Charitas, 248). Ogień karabinowy prowadzi się ponad „bankietem przykopu” (tamże, 148), „zza przykopy” rowu strzeleckiego można także spoglądać (tamże, 285). Pierwszy z nich jest "gliniastą skarpą" - schronieniem oddziałku legionistów, a więc nie są to 'aprosze', z którymi identyfikuje przykopy słownik Doroszewskiego ${ }^{3}$. Drugi, będąc rodzajem przedpiersia, nie wiedzieć czemu różni się rodzajem gramatycznym. Forteca pojawia się już tylko jako metaforyczne określenie Naczelnego Komitetu Narodowego, a twierdza „reakcji jest walizką” (Przeduriośnie, 138, 69).

Równie skromnie rysują się ślady polowych umocnień sowieckich na przedpolach Warszawy: "ciemne doły, każdy z osłoną" (Przedwiośnie, 120) i w ogóle wszelkie „umocnienia wojenne”

${ }^{3}$ Zob. Stounik jezzka polskiego, red. W. Doroszewski, t. 7, Warszawa 1965, s. 550. 
i „szańce”, zarówno te, przy których budowie pracuje Cezary Baryka jeszcze w Baku, gdzie mamy do czynienia między innymi $z$ fosa palisadą, a nawet schronami utworzonymi „poza wałem ziemnym na sposób casemate" (tamże, 60, 63), jak i „obiekty obronne "polskiego militaryzmu»" w postaci prochowni Cytadeli Warszawskiej, której wysadzenie w powietrze wraz z cywilnym otoczeniem gorąco aprobował komunista Lulek. W Przedwiośniu pojawiają się również mury forteczne ( $w$ znaczeniu podstawowym i przenośnym), działobitnia jako element sennego majaku, a z rzeczy nowszych „umocnienia z drutu”, którego kolczastość pominięto, i ziemianki jako element okopów.

Nadal zdarza się „po polsku ścinać z ramienia” (tamże, 176), ale to „ogień karabinowy” (Charitas, 147) ma pierwszeństwo wśród sposobów walki. Gnanie bagnetami, pchnięcia karabinem i wywalanie kolbami zapamiętujemy jako elementy pogromu wsi przymuszonej przez nieprzyjaciela do uczestnictwa w zasadzce (tamże, 157-158).

"Huk wystrzałów ręcznej broni” występuje obok „dostojnego huku armat” albo „grzmotu baterii armatnich" (Charitas, 256, 258, 264), ale strzelaniny również armatniej nie traktuje się $z$ takim pietyzmem i dbałością o dokładne oddanie czynności, obrazu i efektów dźwiękowych, jak to miało miejsce w odniesieniu do epok dawniejszych. Znamienny jest sposób reagowania cywilów w schronie: „strzały armatnie rozlegając się teraz nie hurtownie, lecz detalicznie” (tamże, 265) służą nauczycielce jako pomoc do nauki liczenia w doraźnie zorganizowanej szkole. Świadczy to o zobojętnieniu, sile charakteru odpornego na wszystko i - z całą pewnością — eksterminacji ostatków poetyczności z interesującej nas dziedziny. Opis efektów ostrzeliwania, w którym "gwizdały i furczały jakieś pociski, latały w powietrzu bryzgi żelaznych czerepów” (tamże, 256), trochę przypomina Mantuę albo Sandomierz z Popiołów, tylko tam nie były to ,jakieś” pociski.

Broń i wszelkie środki walki oczywiście występują w świecie utworów, a w tekście - słowa przywołujące je do świadomości i wyobraźni czytelnika, ale nie mobilizują starań twórczych, pojawiają się na zasadzie: jakie są, każdy widzi lub widział. I tak karabin bez dodatkowych zabiegów prezentacyjnych uprzytamnia swój desygnat, i to w postaci aktualnej dla czasu opowiadania. Nawet "muzealny karabin” Cezarego Baryki w bakińskim epizodzie Przedwiośnia jest z pewnością bronią odtylcową i ogólnie rzecz biorąc - współczesną. "Austriackie uzbrojenie” „z okropnymi karabinami” („długie lufy werndlowskich karabinów” wyjaśniaja, jak bardzo to była przestarzała broń) - ma jednak zapewnione miejsce w schematach wyobrażeniowych przynajmniej czytelników współczesnych autorowi.

Pałasz, jak zwykle u tego pisarza utożsamiany z szablą, i bagnet reprezentują broń białą funkcjonującą nadal w realiach wojny i w oddających ją powieściach.

"Szczękający chargot karabinów maszynowych" (Charitas, 264) jest znakiem odnawiania się arsenałów, jak i nowinką nazewniczą. Jeszcze w Nawracaniu Judasza z 1913 roku występują mitraliezy (66). Stanowi to ślad mozolnie zdobywanej samodzielności terminologicznej polskiej wojskowości i ciekawy przykład drobnego zamętu. Otóż w definicji słownikowej znajdujemy: „dawne działko szybkostrzelne o wielu lufach strzelające kartaczami, przestarzała nazwa karabinu maszynowego" ${ }^{4}$.

\footnotetext{
${ }^{4}$ Ibidem, t. 4, Warszawa 1962, s. 744.
} 
Określenie przedmiotu wskazuje na kartaczownicę, ewentualne jej utożsamienie z mitraliezą może mieć źródło w podobieństwie dwóch terminów francuskich: mitraillette — 'kartaczownica' i mitrailleuse - 'karabin maszynowy', przy czym mitraille to 'kartacz' albo rzeczowo z nim związane 'okruchy żelaza'.

„Rewolwer browning” (Charitas, 149) jest błędem rzeczowym (amerykański konstruktor John Moses Browning zajmował się bronią automatyczną i pistoletami samopowtarzalnymi) wynikającym z potocznego utożsamiania rewolweru z pistoletem. Te ostatnie ciągle były w pamięci, i jako broń pojedynkowa także w użyciu, konotowały staroświeckość, a tymczasem stały się nazwą broni od rewolwerów nowocześniejszej.

Armaty manifestują swą obecność raczej z daleka. Nie są przedstawiane unaoczniająco, jak na przykład w Popiotach.

Amunicję reprezentują szrapnele, pociski i kule, a wśród nich nieprzyjacielskie, moskiewskie, zwykłe karabinowe, błędne (takie trafiały się i pod Raszynem, ale teraz strzelano „nieszczędnie”, więc występowały liczniej i stały się groźniejsze), wreszcie „wielkie pociski armatnie” i „wielkie stożkowe armatnie kule" (Przedwiośnie, 53, 93), których dodatkowe określenie świadczy o pamiętaniu podstawowego znaczenia i zgodnego $\mathrm{z}$ nim, jeszcze nie tak dawno — kształtu pocisków.

Splot przyczyn sprawil, że ekspozycji rzeczywistego, wówczas nowego środka walki w prozie Żeromskiego trzeba jednak szukać w Wietrze od morza, wydanym tuż po „wielkiej wojnie”, w opowiadaniu, któremu redakcja nadała tytuł Otto v. Arfberg. Jest to „łódź podwodna U-72a” (231).

Okręt cesarskiej marynarki wojennej o takiej nazwie istniał rzeczywiście, działał jednak na Morzu Śródziemnym i na Adriatyku, a nie na Bałtyku, ten podwodny stawiacz min 1 listopada 1918 roku uległ samozatopieniu w Kotorze.

Przede wszystkim należy podkreślić wyjątkowość tego opowiadania. Zawarty w nim opis okrętu, wówczas niezwykłego dla ogółu, jest pierwszy w literaturze kraju, który dostęp do morza właśnie uzyskał, flotę wojenną miał symboliczną, pierwszą jednostkę przedstawionego typu uzyskał niemal dziesięć lat po ukazaniu się utworu.

Jest bardzo prawdopodobne, że autor nigdy nie widział opisywanego obiektu, posilkując się trudno zresztą dostępnymi materiałami i relacjami podwodników z flot państw zaborczych. Liczne motywy czynią również prawdopodobnym kontakt na przykład z kimś z misji wojskowej, jakieś francuskie źródła lub korzystanie ze znajomości języka francuskiego do tworzenia nazw i terminów, które w polszczyźnie nie zdążyły jeszcze zaistnieć. A więc ogromnie skomplikowany przedmiot miał się objawić dzięki słowom, ale słowom, których jeszcze nie było, a nawet brakowało wzorów, według których należałoby je tworzyć.

Terminologia osacza czytelnika od pierwszych stron: „Komory water-balastu”, po chwili pojawia się przekład i opis działania zawierający kolejny wtręt tym razem francuski — „do jednej z robinet, przez które komory obciążające łódź wodą komunikują się (..) z otchłanią morza" (Wiatr od morza, 231). Polski kurek brzmiał zbyt powszednio, nie został więc użyty. Mechanizm zanurzenia-wynurzenia, prosty tylko pod względem zasady, w szczegółowym przedstawieniu stawał się trudny, zwłaszcza gdy niedostatek terminów dotyczył praktycznie wszystkiego: „powietrze ścieśnione, pchnięte z basenów przez kierownika łodzi [nazywanego też trafniej „komendan- 
tem tej łodzi”, „kapitanem” i nie wiedzieć czemu „komodorem”] nie mogło podołać zadaniu wydalenia całkowicie brył wodnych [sic!] z komory" (231). Nasuwa się spostrzeżenie, jak użyteczna jest na przykład nazwa zbiornik, bądź co bądź współczesnie już używana (Sewer, Józef Weyssenhoff, Wiktor Gomulicki) i odnotowana w Stowniku Wileńskim jako „miejsce umyślnie urządzone dla zbioru lub przechowywania wody — niekiedy oznacza 'przyjemnik', 'zbieradło",5. Dla świadomości językowej pisarza, w pierwszej ćwierci XX wieku nie ustaliła się jeszcze, dziś dla nas oczywista, dystrybucja nazw pomiędzy zblizone funkcjonalnie desygnaty — basen był więc równie dobry.

Statek, choć w innym opowiadaniu cyklu występuje poprawny nazewniczo okręt wojenny, przypomina cywilnemu prezenterowi „hermetycznie zakorkowaną butelkę” - czytelnikowi, jeśli w ogóle przypomina cokolwiek, jest to przypadkowe, niezborne i całkowicie nieprzydatne do wytworzenia wyobrażalnej całości. Autor stanął przed zadaniem podobnym do kreacyjnych kłopotów science fiction i wywiązywał się z niego, jak tylko było to możliwe. Wśsód nazw utrudniających adekwatne wyobrażenie obiektu są: „izba załogi”, „nawa centralna” — odpowiadająca centrali dowodzenia, „skrytka oficerska”, a w niej zapewne „łóżeczka oficerów” — deminutitum związane z ciasnota pomieszczeń, ale konotacyjnie fatalne! — "gabinet dowódcy" — także zamącający stosowne wyobrażenie charakteru i rozmiarów pomieszczeń, wreszcie „kotłownia” — bez kotłów, przy czym "gazowym” nazywany napęd kazałby raczej mówić o maszynowni, ale tu zadziałało nieadekwatne przyzwyczajenie nazewnicze. Całkowicie poprawna jest natomiast „wyrzutnia torped” (232), choć kiedy indziej nazywa się poetyzująco „złowieszczym łożyskiem straszliwej torpedy” (269), lub skoro torpedę można uzna za pocisk, wyrzutnia stanie się jego lufą (254), wreszcie kiosk komendanta — istotnie tak nazywany, zwłaszcza kiedy okręty podwodne były jeszcze łodziami.

Najgorzej wytrzymały próbę czasu, i chyba były najmniej użyteczne również dla współczesnego odbiorcy, fragmenty, w których niedostatek informacji i możliwości języka usiłował Żeromski nadrobić poetycką emfazą.

Oglądał okiem znawcy i poskromiciela owe wewnątrz statku dzikie zwierzęta uśpione, które drzemały posłusznie gotowe ocknąć się i wybuchnąć na każde jego skinienie w głębokości siedmiu metrów pod wodą (232).

Wiele wskazuje, że mowa tu o torpedach. Kombinacja informacji i zmyśleń wskazuje jednak, że autor jakimś źródłem wiedzy dysponował sumiennie, choć nie zawsze kompetentnie. Torpedy nie wybuchały na skinienie, lecz zaledwie były wystrzeliwane i procent wybuchnięć w wyniku trafienia wcale nie był imponujący. Imponowała jednak sama broń, która poruszając wyobraźnię pisarza, czyniła w niej trochę zamętu:

Wielkie stalowe cygaro, ów złowrogi statek [sic!] samopas w wodach chodzący, o czterdziestu pięciu centymetrach średnicy [kaliber ten utrzymywał się na okrętach francuskich i rosyjskich, na niemieckich - tylko małych i produkcji przedwojen-

${ }^{5}$ Stownik jezzka polskiego..., t. 2, Wilno 1861, s. 1097. 
nej-R. H.], podzielony wewnętrznie na liczne oddziały, zawierające wybuchowy ładunek stu kilogramów bawełny strzelniczej [mimowolny archaizm - R. H.], zaopatrzony w narzędzia, które mu zapewniają utrzymanie się w biegu, prędkość i kierunek (...) pognał z szybkością siedemdziesięciu kilometrów na godzinę pozostawiając po sobie białą strzępiastą smugę (250).

Próba rozszerzenia przez autora narracji przez uwzględnienie prawdziwych informacji ukazuje ich ograniczenia: „z gyroskopem zabezpieczającym linię niezmienną jej biegu, szybka dzięki ogrzaniu powietrza w chwili wtłaczania go w piąty przedzial pocisku" (254) - torpeda paroga zowa działa jednak niezupełnie tak. Uniesienia laika, trud mistrza słowa, na którym spoczęło wyjątkowe zadanie, i rzetelność informacyjna posunięta do granic możliwości w tym czasie i warunkach nie zawsze przynosily efekt:

...olbrzymie cylindry, potężnie nitami skowane [moc zespolenia nie kojarzyła się jeszcze ze spawaniem - R. H.], leżące wzdłuż ścian łodzi, lufy [!?] gruboskórne, w których wnętrzu zawiera się powietrze ścieśnione, owa siła fundamentalna istnienia, oddechu i działania, zanurzania się i wypływania, a wreszcie moc zadawania śmierci wrogom (232)

— istotnie torpedy wyrzucano za pomocą sprężonego powietrza, a i poprzednie jego zastosowania nie odbiegaly od rzeczywistości.

Płynęli na powierzchni wręcz niesłychanie szybko:

Wnet zatoka gdańska została w tyle, Hel począł uchylać się w piany. Wystrzeliła przed oczy szczecińska smuga ziemi (234),

natomiast pod wodą — z szybkością „zaledwie szesnastu kilometrów na godzinę” (248) wbrew sugestiom było to bardzo dobre tempo i zdołano je wydatnie zwiększyć dopiero pod koniec następnej wojny światowej.

Realistyczne są jednak „piany”, które „przelatywały przez wąski pokładzik”(234) i niewyczytany, niezobaczony na ilustracji, niewymyślony „specyficzny zapach wnętrza” (248) po zanurzeniu się łodzi. Przypuszczalny informator musiał być bardzo dokładnie wypytywany — pisarz chciał wiedzieć, bo miał przedstawić rzetelnie. Z kolei zredukowanie załogi do dwudziestu ludzi, kiedy już na początku wojny słynny, choć niewielki U-9 obsługiwało dwudziestu ośmiu, mogło być wynikiem pośredniej choćby obserwacji - jeśli odliczyć wachtę maszynową, tylu mogło stać na pokładzie w paradnym szeregu, na przykład na fotografii.

Niesprawiedliwe i ahistoryczne byłoby jednak traktowanie opowieści o U-72 tak, jakby powstała w warunkach oczywistości przedmiotów i powszechnej znajomości ich ustalonych nazw. Świadectwem skrupulatności dokumentarnej pisarza niestrudzenie poszukującego prawdy i usiłującego ją przedstawić bywają czasem drobiazgi. Marynarze ubota „mieli zamiar wyłowić na pamiątkę zwycięstwa" czapkę kapitana zatopionego statku (254). Istotnie był to jeden ze zwyczajowych dowodów odniesionego sukcesu. 
O znaczeniu utworu, jego wartości nie decydują techniczne opisy okrętu, które czasem pozostawały enigmatyczne mimo objaśnień, ale utrwalona w nim pasja odkrywcy spraw morza — pisarza, który właściwym sobie sposobem i środkami także zdobywał je i osadzał w mowie i świadomości. 